\title{
An Investigation Into Postgraduate Students' Knowledge of and Attitude Towards Using E-learning Platform
}

\author{
Munthir Alblaihed \\ Hail University- KSA, Hail, \\ Saudi Arabia \\ M.alblaihed@uoh.edu sa
}

\begin{abstract}
The study aimed to identify the relationship between students' knowledge and their attitudes towards using the e-learning platform. As well as to identify the possibility of predicting students' trend towards using the e-learning platform based on their knowledge of using it, their study status (campus/ distance learning), their gender, and their first language. The questionnaires were prepared to measure two main structures, students' knowledge of using the e-learning platform and their attitude towards it. The study sample included students attending a master's and doctoral as part of the British university course process. The sample consisted of 48 students (total students in this course), 29 students on campus $(60 \%)$, and 19 students in distance learning $(40 \%)$. The results revealed no correlation between students' knowledge and their attitudes towards using the learning platform. The existence of a positive trend towards the use of the e-learning platform among students registered through the e-learning platform more than the students registered on the university campus, the absence of statistically significant differences attributed to the effect of gender, based on their first language, in terms of predicting students' knowledge and their tendency towards using E-learning platform based on variables (status, gender and first language). It was found that the students' condition is an indicator of the situation that may indicate further study to investigate new factors that may affect students' knowledge and their attitude towards using the e-learning platform.
\end{abstract}

Keywords - E-learning platform, ICT, Postgraduate students.

\section{INTRODUCTION}

A $\mathrm{s}$ a result of the technological revolution and the rapid development of the information technologies that have become an irreplaceable part of people's lives, there are increasing demands for employing these technologies to confront the ever-increasing skill and knowledge requirements of modern life and to enhance teaching and learning. Nowadays, there is a great deal of debate about incorporating technology into higher education practice, which has been strongly promoted by policymakers to enhance students' learning experience [1].

\section{Literature review}

Universities around the world are facing huge demands to employ technology in their programs due to many reasons. Macharia and Pelser argue that at least three important factors that integrate technology applications into universities practice a crucial matter [2]. The first factor is the changing nature of higher education and its landscape caused by many forces related to many aspects such as lifestyle, culture, and other local and global influences. The second factor is the students' and teachers' needs for more flexible teaching and learning. They added that the need for more quality educational practices could be seen as the third factor in making technology integration crucial for universities.

In recent years, the common incorporation of technology into university practice has been networking as a form of electronic learning. This form of learning through information and communication technologies has made a revolution like higher education practice due to its affordances for all the stakeholders in education [3]. Consequently, universities have paid considerable attention to this form of technology that 
could provide many features to increase education quality and shift it from the traditional way of teaching [4];[5]. It is also argued that this form of technology could provide teachers and students with the flexibility of time where they can perform their tasks without any time or place restrictions [3]. They added that this form of technology, as a learning platform, can solve many issues related to geographic mobility, job commitments, distance learning and training, and traffic issues, especially in crowded cities [6].

Many other researchers have suggested that this technology can enhance learning in many ways, for example, in gathering resources, sharing opinions and materials with others, supporting meaning-making, and putting students in a position that allows them to interact with communities to build knowledge [7]; [8]; [9]; [10]. Moreover, networking and elearning technologies in general are thought to be a useful environment to assist the increasing number of distance learning and part-time students and those students who spend a lot of time off-campus [3].

Although many researchers agreed on the importance of technology applications for higher education, others identified many issues that could influence technology's introduction into educational practice. For example, the user's beliefs and ideas about the contribution of technology to teaching and learning processes. Their experience with an ability to use this technology effectively, the availability of resources that support technology implementation, and, finally, community encouragement and support [11].

Also, Postholm argued that the value of using technology in education depends on the teachers and students and the nature of the skills and opportunities that technology could provide in a specific context [12]. Furthermore, researchers found that several factors could influence the use of and the attitudes towards technology in education, such as gender, age, and knowledge of technological and pedagogical aspects [13].

As it has been recommended that further research is needed to be done in this area, the current small-scale study attempts to provide useful findings of postgraduate students' knowledge of and attitudes towards using an e-learning platform hosted by a British university.

\section{Aims of the study}

This small-scale study aims to explore postgraduate students' knowledge of using e-learning platforms and their attitude towards this experience as a part of the course process. The study will seek to explore the following points:

1- The relationship between postgraduate students' knowledge of using e-learning platform and their attitudes towards it.

2- The relationship between the students' status (campus or distance learning student) and their attitude towards using elearning platform.

3-The relationship between the students' gender and their attitude towards using e-learning platform.

4- The relationship between the students' first language and their attitude towards using e-learning platform.
5- The possibility of predicting the students' knowledge of using e-learning platform based upon their attitude towards it, their status, gender and first language.

6- The possibility of predicting the students' attitude towards using e-learning platform based upon their knowledge of using it, their status, gender and first language.

\section{Methodology}

In this small-scale quantitative study, the instrument that has been designed to meet the purposes of the study is a closedended questionnaire; this research design is appropriate for studies that seek to obtain a numeric description of trends, attitudes, or opinions of a population by studying a sample from this population [14].

\section{The sample}

The study sample was conveniently selected from students who were attending Master and Ph.D courses in a British university. The sample consisted of 48 students (the whole population of the students in this course), 29 on-campus students (60\%), and 19 distance learning students (40\%).

\section{The instrument}

The study measures two main constructs, the students' knowledge of using e-learning platform and their attitude towards it. The questionnaire consists of these two constructs in addition to an introductory part as follows:

1- An introduction about the purposes of the study and the guarantee of the confidentiality and anonymity of the participants' data, followed by questions about the participants' background information including gender (male or female), status (on-campus or distance learning students) and first language (English or other).

2- The knowledge test, which contains 10 multiple choices questions that measure the students' knowledge about how to use the e-learning platform. The questions were drawn from the instructions on using the platform on the website of the university by considering the basic knowledge that enables students to use the website effectively. In this part, the participants were asked to provide a single response to each question by choosing one from four answers provided.

3- The attitude scale which contains 26 statements. In this part, the participants were asked to indicate the extent in which they agree or disagree with the statements by choosing the relevant box according to a Likert scale (strongly agree, agree, neither agree nor disagree, disagree, and strongly disagree). Each statement has a value from 5 to 1 and the negative statements' values were reversed in order to maintain consistency and to remove the impact of the statements' direction. The total score of the attitude scale is between 26 and 130. A higher score indicates a more positive attitude and a lower score indicates a more negative attitude towards the e-learning platform.

\section{Administration of the instrument}

After obtaining the necessary permissions to conduct the study from the program director and obtaining ethical approval, the 
program admissions office sent the questionnaires to the 48 students by email. Only 29 questionnaires were completed and returned, made up as follows: 15 male (52\%) and 14 female (48\%), 20 on-campus (69\%) and nine distance learning students (31\%), 9 students whose first language is English (31\%) and 20 students whose first language is not English (69\%). In order to avoid any ethical issues that could occur during the research process, the researcher considered the British Education Research Association ethical guidelines when collecting the data by having permission from the director of the program to collect the data and by considering the confidentiality and anonymity of the participants.

\section{Validity}

"The validity of a scale refers to the degree to which it measures what it is supposed to measured" [15]. The items of the instrument were verified by content validity. Experts reviewed them to check their validity. The experts suggested a few changes to be made to the knowledge part of the instrument. As a result of the experts' suggestions, the researcher changed the knowledge questions from the style: "Do you know how to ....?" with the answer "yes" or "no" to a multiple-choice format. Moreover, the experts suggested rewording some items in the attitude scale, which was subsequently done.

\section{Reliability}

Pallant defined reliability as "the degree to which the items that make up the scale are all measuring the same underlying attribute" [15]. He explained that the internal consistency could be tested in a number of ways, and the most common test is Cronbach's alpha, which is available using SPSS. The test's value is in the range from 0 to 1 ; a higher value indicates greater reliability. A value of alpha greater than 0.7 is generally regarded as acceptable. Due to time limitations and the relatively small number of students in the course, the reliability of the questionnaire was tested after the researcher collected the data. However, this test should be done at the pilot stage to improve the questionnaire and make sure that it can do the job for which it is needed as indicated [16]. Table 2.1 below shows that the value of Cronbach's alpha of the knowledge scale was 0.525 . This value shows that the scale reliability was low.

Table 2.1

Reliability of the knowledge test

\begin{tabular}{|c|c|c|}
\hline Cronbach's Alpha & $\begin{array}{c}\text { Cronbach's Alpha } \\
\text { Based on } \\
\text { Standardized } \\
\text { Items }\end{array}$ & N of Items \\
\hline .525 & .492 & 10 \\
\hline
\end{tabular}

To improve the reliability of the knowledge test, the researcher considered the items statistics SPSS output that shows the value of Cronbach's alpha if items were deleted and decided to remove questions 1 and 7 from the ten questions to improve the reliability of the test. The new value after removing the two items was 0.606 , which means that the test is more reliable. While the minimum value of Cronbach's alpha should be 0.7 , it is worth mentioning that "when there are a small number of items in the scale (fewer than 10) Cronbach alpha can be quite small" [15: 6]. The following table 2.2 below shows the new value of Cronbach's alpha after the removal of question 1 and 7

Table 2.2

Reliability of the knowledge test after the removal of question 1 and 7

\begin{tabular}{|c|c|c|}
\hline $\begin{array}{c}\text { Cronbach's } \\
\text { Alpha }\end{array}$ & $\begin{array}{c}\text { Cronbach's } \\
\text { Alpha Based on } \\
\text { Standardized } \\
\text { Items }\end{array}$ & N of Items \\
\hline .606 & .564 & 8 \\
\hline
\end{tabular}

Cronbach's alpha was also used to test the reliability of the attitude scale, and the value was 0.860 , which means that the reliability of the attitude scale is very high. Table 2.3 shows the value of Cronbach's alpha for the attitude scale.

Table 2.3

Reliability of the attitude scale

\begin{tabular}{|c|c|c|}
\hline Cronbach's Alpha & $\begin{array}{c}\text { Cronbach's Alpha } \\
\text { Based on } \\
\text { Standardized } \\
\text { Items }\end{array}$ & N of Items \\
\hline .860 & .851 & 26 \\
\hline
\end{tabular}

\section{Data analysis and results}

\section{Checking the normality of the knowledge scale}

The Kolmogrov-Smirnov test ascertained the normality of the distribution of the scores on the knowledge test. The significance of the K-S test was 0.052, as shown in Table 3.1 below. This value shows that the knowledge scores' distribution is not significantly different from normality ( $p>05)$. This means that the knowledge scores are normally distributed, which allows the use of parametric tests

Table 3.1

Kolmogorov-Smirnov test of normality for the knowledge test

\begin{tabular}{|l|r|r|r|r|r|r|}
\hline \multirow{2}{*}{} & \multicolumn{3}{|c|}{ Kolmogorov-Smirnov } & \multicolumn{3}{|c|}{ Shapiro-Wilk } \\
\cline { 2 - 7 } & Statistic & \multicolumn{1}{c|}{ df } & Sig. & Statistic & df & Sig. \\
\hline $\begin{array}{l}\text { Total } \\
\text { knowledge }\end{array}$ & .161 & 29 & .052 & .931 & 29 & .060 \\
\hline
\end{tabular}

a. Lilliefors Significance Correction

\section{Checking the normality of the attitude scale}

The normality of distribution of the attitude scores was also tested by the Kolmogorov-Smirnov test. The significance level of the K-S statistic was 0.20 as shown in Table 3.2 below ( $p>.05)$. This value shows that the distribution of the attitude 
scores is not significantly different from normality. This means that the attitude scores are normally distributed which allows use of parametric tests.

Table 3.2

Kolmogrov-Smirnov test of normality for the attitude scale

\begin{tabular}{|l|r|r|r|r|r|r|}
\hline & \multicolumn{3}{|c|}{ Kolmogorov-Smirnov $^{\mathrm{a}}$} & \multicolumn{4}{|c|}{ Shapiro-Wilk } \\
\cline { 2 - 7 } & Statistic & df & Sig. & Statistic & df & Sig. \\
\hline Total attitude & .083 & 29 & $.200^{*}$ & .973 & 29 & .657 \\
\hline
\end{tabular}

a. Lilliefors Significance Correction

*. This is a lower bound of the true significance.

\section{Results of the hypotheses}

Results of hypothesis $\mathrm{H1}$

H1: There will be a positive correlation between the students' knowledge of using e-learning platform and their attitude towards it. (Rejected).

H01: There will be no significant correlation between the students' knowledge of using e-learning platform and their attitude towards it.(Accepted).

The Pearson correlation coefficient measured the relationship between the students' knowledge of using elearning platforms and their attitude. The result did not seem to show any relationship between knowledge and attitude. A one-tailed test was used because the direction of the correlation was predicted to be positive. It was thought that students with a more positive attitude towards using the platform would be likely to make greater use of the platform and thus gain more knowledge about how to use it effectively. The correlation Table 3.3 shows that the Pearson correlation coefficient $\mathrm{r}=0.174$ and $\mathrm{p}>0.05$. Therefore, there is no statistically significant correlation between the students' knowledge of using e-learning platforms and their attitude. Therefore, hypothesis H1 is rejected, and null hypothesis H01 is accepted..
Table 3.3

Correlation between knowledge and attitude

\begin{tabular}{|lc|c|c|}
\hline & & & total \\
& & total attitude & knowledge \\
\hline total attitude & $\begin{array}{c}\text { Pearson Correlation } \\
\text { Sig. (1-tailed) } \\
\end{array}$ & 1 & .174 \\
& $\mathrm{~N}$ & 29 & .183 \\
total & Pearson Correlation & .174 & 29 \\
knowledge & Sig. (1-tailed) & .183 & 1 \\
& $\mathrm{~N}$ & 29 & 29 \\
\hline
\end{tabular}

\section{Results of hypothesis $\mathrm{H} 2$}

H2: Distance learning students will have a more positive attitude towards using e-learning platform than on-campus students. (Accepted) .

H02: There will be no significant difference in attitude towards using e-learning between on-campus students and distance learning students. (Rejected) .

The mean attitude scores for the on-campus students and for the distance learning students were computed as shown in Table 3.4.

Table 3.4

Group Statistics

\begin{tabular}{|ll|r|r|r|c|}
\hline & Status & N & Mean & $\begin{array}{c}\text { Std. } \\
\text { Deviation }\end{array}$ & $\begin{array}{c}\text { Std. Error } \\
\text { Mean }\end{array}$ \\
\hline Total & campus & 20 & 70.2000 & 11.77687 & 2.63339 \\
attitude & distance & 9 & 87.1111 & 12.00463 & 4.00154 \\
\hline
\end{tabular}

From the table, it is seen that the distance learning students have a higher mean score $(M=87.1$, sd $=12.0)$ than the oncampus students $(\mathrm{M}=70.2, \mathrm{sd}=11.8)$.

Table 3.5

Independent Samples Test

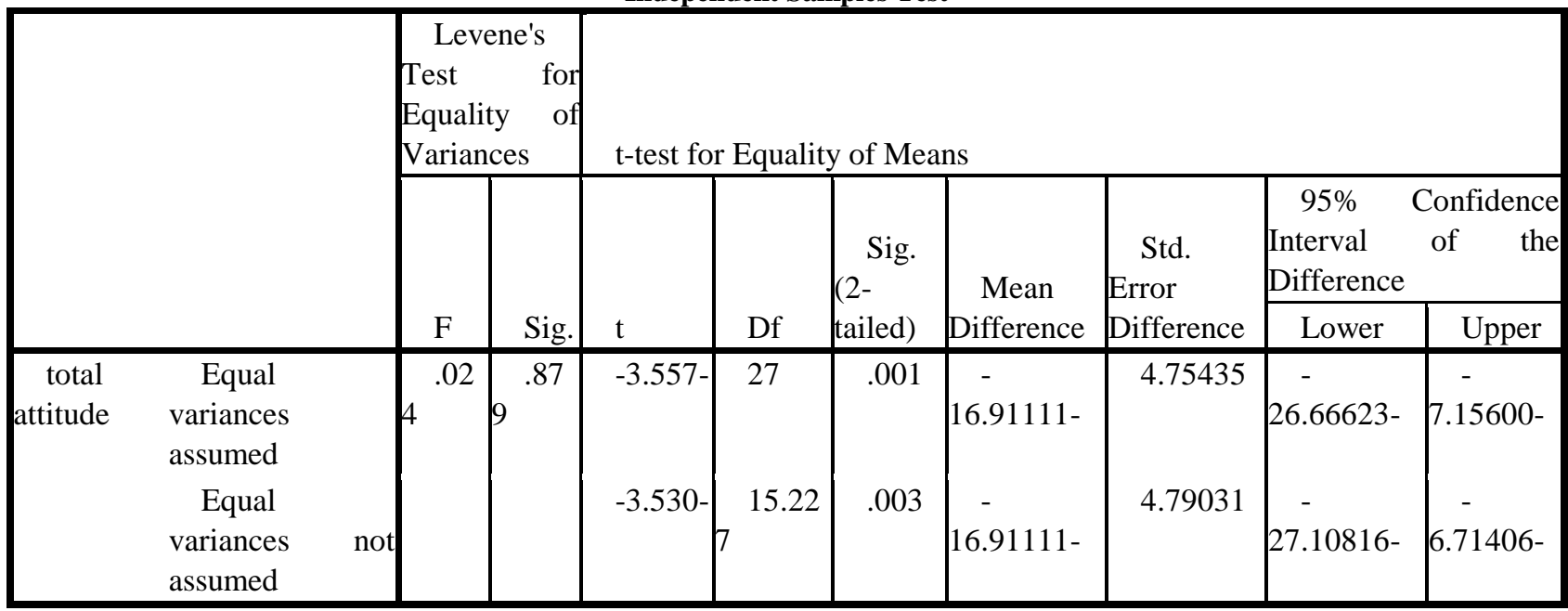


A t-test for two independent samples was carried out to test whether the difference between the means was statistically significant (Table 3.5 above). Not assuming equal variances, the significance level $\mathrm{p}<0.01$, indicating that the means are significantly different at the $\mathrm{p}=0.01$ level. Therefore, hypothesis $\mathrm{H} 2$ is accepted and null hypothesis $\mathrm{H} 02$ is rejected.

\section{Results of hypothesis $\mathrm{H3}$}

H3: There will be a significant difference in attitude towards using e-learning between male and female students. (Rejected) H03: There will be no significant difference in attitude towards using e-learning between male and female students. (Accepted). not assumed). See Table 3.7 below.
The mean attitude scores for male and female students were computed as shown in Table 3.6.

\begin{tabular}{|c|c|c|c|c|c|}
\hline \multicolumn{2}{|c|}{ Gender } & $\mathrm{N}$ & Mean & $\begin{array}{c}\text { Std. } \\
\text { Deviation }\end{array}$ & $\begin{array}{c}\text { Std. Error } \\
\text { Mean }\end{array}$ \\
\hline \multirow[t]{2}{*}{ totalattitude } & male & 15 & 77.3333 & 15.94932 & 4.11810 \\
\hline & female & 14 & 73.4286 & 12.06211 & 3.22373 \\
\hline
\end{tabular}

The table shows that for male students, $\mathrm{N}=15, \mathrm{M}=77.3$ and $\mathrm{sd}=15.9$, while for female students, $\mathrm{N}=14, \mathrm{M}=73.4$ and $\mathrm{sd}=12.1$. The difference in the means was shown to be not statistically significant $(\mathrm{p}>0.05$, two tailed, equal variances

Table 3.7

Independent Samples Test

\begin{tabular}{|c|c|c|c|c|c|c|c|c|c|c|}
\hline & \multicolumn{2}{|c|}{$\begin{array}{c}\text { Levene's Test for } \\
\text { Equality of } \\
\text { Variances }\end{array}$} & \multicolumn{7}{|c|}{ t-test for Equality of Means } \\
\hline & & \multirow[b]{2}{*}{$\mathrm{F}$} & \multirow[b]{2}{*}{ Sig. } & \multirow[b]{2}{*}{$\mathrm{t}$} & \multirow[b]{2}{*}{ Df } & \multirow{2}{*}{$\begin{array}{l}\text { Sig. }(2- \\
\text { tailed) }\end{array}$} & \multirow{2}{*}{$\begin{array}{c}\text { Mean } \\
\text { Difference }\end{array}$} & \multirow{2}{*}{$\begin{array}{l}\text { Std. Error } \\
\text { Difference }\end{array}$} & \multicolumn{2}{|c|}{$\begin{array}{l}95 \% \text { Confidence Interval of } \\
\text { the Difference }\end{array}$} \\
\hline & & & & & & & & & Lower & Upper \\
\hline totalattitude & $\begin{array}{l}\text { Equal variances } \\
\text { assumed }\end{array}$ & 1.206 & .282 & .739 & 27 & .466 & 3.90476 & 5.28099 & $-6.93094-$ & 14.74047 \\
\hline & $\begin{array}{l}\text { Equal variances } \\
\text { not assumed }\end{array}$ & & & .747 & 25.930 & .462 & 3.90476 & 5.22984 & $-6.84674-$ & 14.65627 \\
\hline
\end{tabular}

Therefore, hypothesis $\mathrm{H} 3$ is rejected and null hypothesis $\mathrm{H} 03$ is accepted which means that there is no gender difference in attitude towards using e-learning among the students.

\section{Results of hypothesis $\mathrm{H4}$}

H4: Students whose first language is English will have a more positive attitude towards using e-learning than students whose first language is not English. (Rejected)

H04: There will be no significant difference in attitude towards using e-learning between students whose first language is English and students whose first language is not English. (Accepted).

The mean attitude scores for students whose first language is English and for students whose first language is not English were computed as shown in Table 3.8.
Table 3.8

Group Statistics

\begin{tabular}{|ll|r|r|r|c|}
\hline \multicolumn{1}{|c|}{$\begin{array}{l}\text { First } \\
\text { language }\end{array}$} & $\mathrm{N}$ & Mean & $\begin{array}{c}\text { Std. } \\
\text { Deviation }\end{array}$ & $\begin{array}{c}\text { Std. } \\
\text { Error } \\
\text { Mean }\end{array}$ \\
\hline totalattitude & English & 9 & 78.1111 & 19.08170 & 6.36057 \\
& other & 20 & 74.2500 & 11.60252 & 2.59440 \\
\hline
\end{tabular}

The table shows that for the students whose first language is English, $\mathrm{N}=9, \mathrm{M}=78.1$ and $\mathrm{sd}=19.1$, while for students whose first language is not English, $\mathrm{N}=20, \mathrm{M}=74.3$ and $\mathrm{sd}=11.6$. The difference in the means was shown to be not statistically significant ( $\mathrm{p}>0.05$, two tailed, equal variances not assumed). See Table 3.9. 
Table 3.9

Independent Samples Test

\begin{tabular}{|c|c|c|c|c|c|c|c|c|c|c|}
\hline & \multicolumn{2}{|c|}{$\begin{array}{c}\text { Levene's Test } \\
\text { for Equality } \\
\text { of Variances }\end{array}$} & \multicolumn{7}{|c|}{ t-test for Equality of Means } \\
\hline & & \multirow[b]{2}{*}{$\mathrm{F}$} & \multirow[b]{2}{*}{ Sig. } & \multirow[b]{2}{*}{$\mathrm{t}$} & \multirow[b]{2}{*}{ Df } & \multirow{2}{*}{$\begin{array}{l}\text { Sig. (2- } \\
\text { tailed) }\end{array}$} & \multirow{2}{*}{$\begin{array}{c}\text { Mean } \\
\text { Difference }\end{array}$} & \multirow{2}{*}{$\begin{array}{l}\text { Std. Error } \\
\text { Difference }\end{array}$} & \multicolumn{2}{|c|}{$\begin{array}{l}95 \% \text { Confidence } \\
\text { Interval of the } \\
\text { Difference }\end{array}$} \\
\hline & & & & & & & & & Lower & Upper \\
\hline totalattitude & $\begin{array}{l}\text { Equal variances } \\
\text { assumed } \\
\text { Equal variances } \\
\text { not assumed }\end{array}$ & 2.302 & .141 & $\begin{array}{l}.676 \\
.562\end{array}$ & $\begin{array}{r}27 \\
10.758\end{array}$ & $\begin{array}{l}.505 \\
.586\end{array}$ & $\begin{array}{l}3.86111 \\
3.86111\end{array}$ & $\begin{array}{l}5.71347 \\
6.86933\end{array}$ & $\begin{array}{r}{ }^{-} \\
7.86196- \\
- \\
11.29978\end{array}$ & $\begin{array}{r}15.584 \\
18 \\
19.022 \\
00\end{array}$ \\
\hline
\end{tabular}

Therefore, hypothesis $\mathrm{H} 4$ is rejected and null hypothesis $\mathrm{H} 04$ is accepted which means that there is no difference in attitude towards using e-learning between students whose first language is English and students whose first language is not English.

\section{Testing the assumptions of multiple regression}

The independent variables' multicollinearity was checked, and the bivariate correlations were found to be above 0.7 , so all the variables were retained. This was confirmed by the $t$ tolerance value higher than 0.10 and the VIF statistics, which were lower than 10. The normal probability P-P Plot (Figure 3.6) revealed that the points did not form a straight diagonal line from the bottom left to the top right, suggesting that the data were not linear. The scatterplot of standardized residuals revealed that most of the scores were not concentrated in the center, suggesting a lack of homoscedasticity (Figure 3.7) .

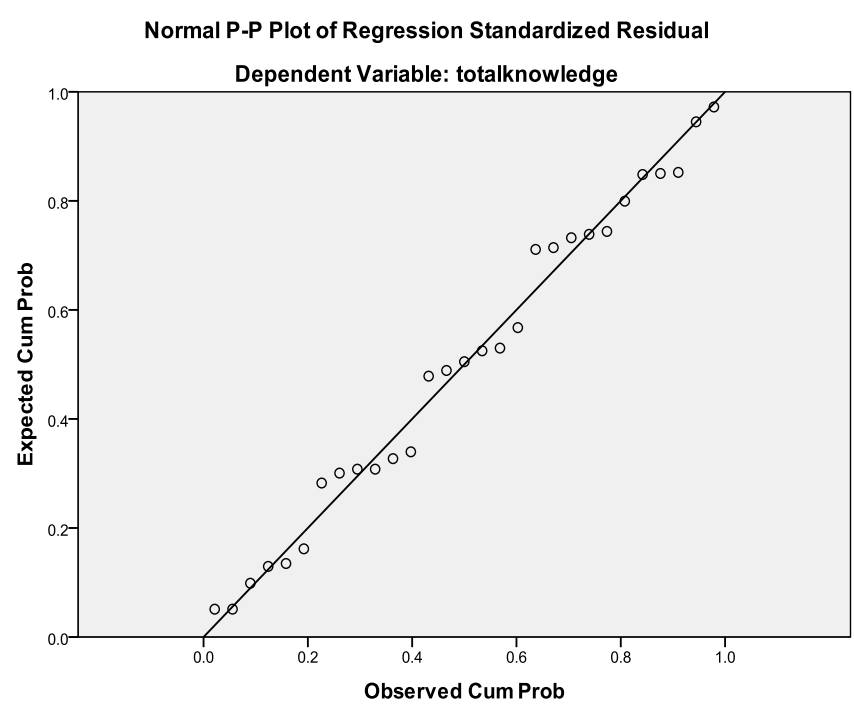

Figure 3.6 Normal P-P plot of regression

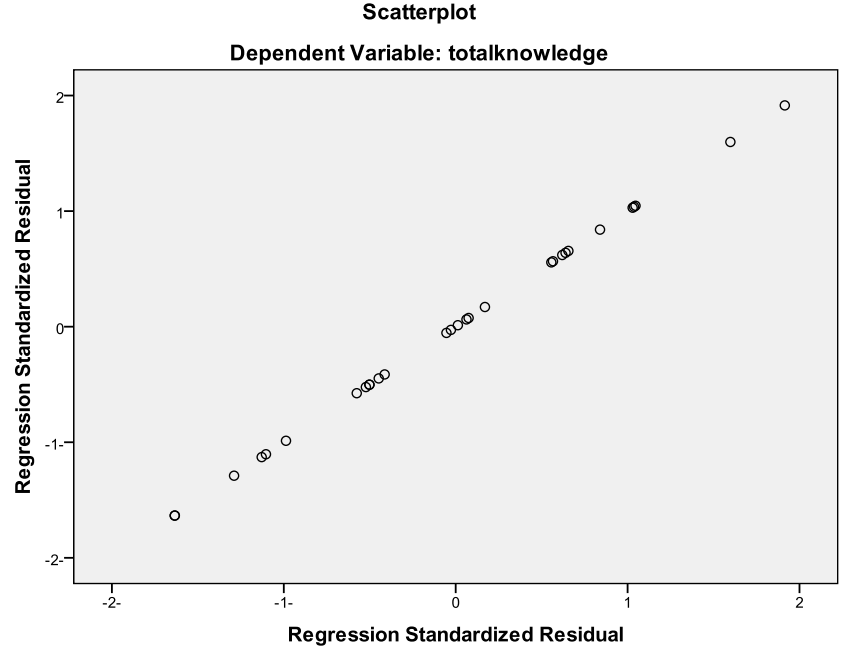

Figure 3.7

Scatterplot of regression

The histograms and box and whiskers plots of the knowledge and attitude scores show that there are no outliers (Figures 3.8 and 3.9). 


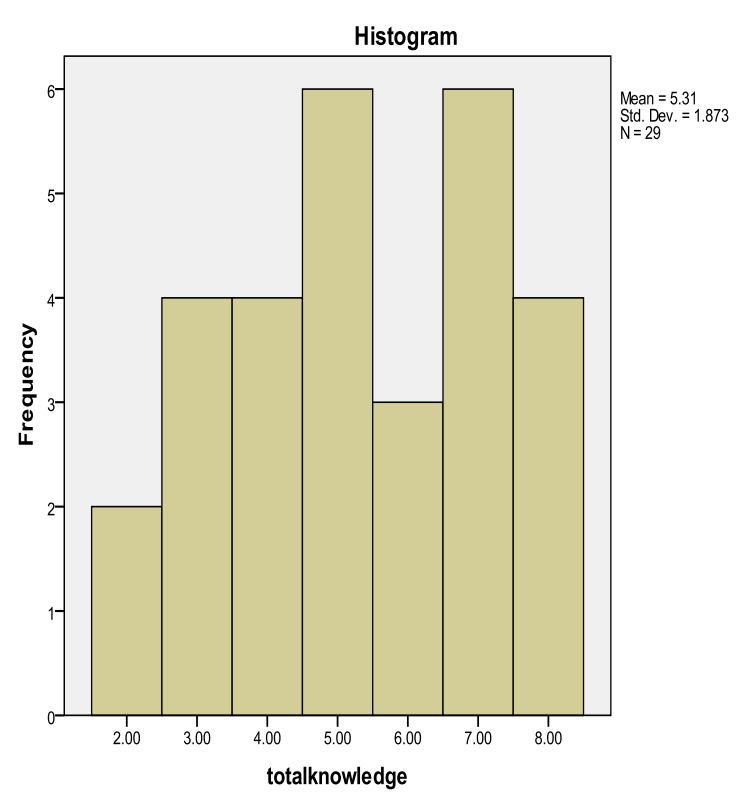

Figure 3.8

Histogram of total knowledge distribution

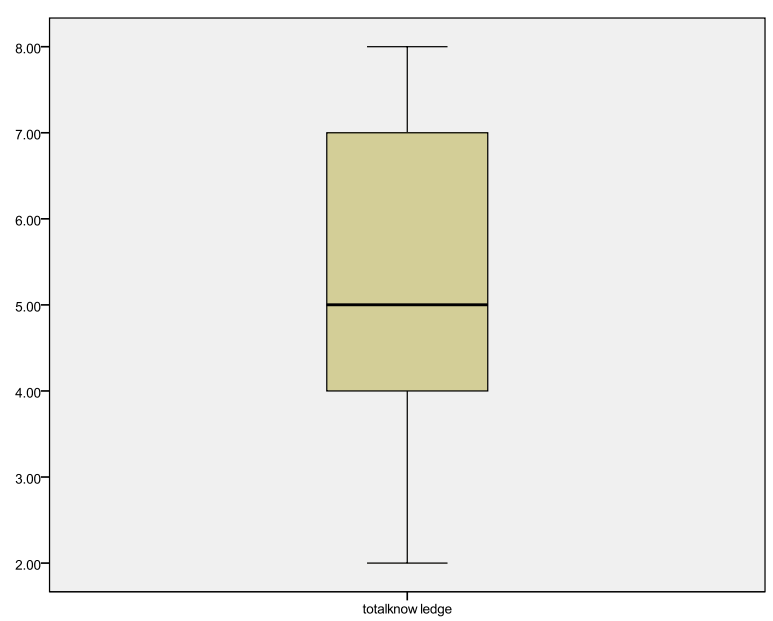

Figure 3.9

Whiskers plot of the knowledge scores

The sample size (29 participants) is too small to run a generalizable multiple regression. Since there are 4 independent variables and participants per predictor are needed for a reliable equation according to [15: 150], I would need a sample size of at least 60 participants.

Therefore, only some of the assumptions of multiple regressions are met in my data. The assumptions of multicollinearity and no outliers, and of normality of distribution are met. On the other hand, there is a lack of linearity and homoscedasticity, and the sample is too small. Nevertheless, for the purpose of this study the multiple regressions have been carried out.

\section{Results of hypothesis $\mathrm{H5}$}

H5: MSc students' knowledge of using e-learning platform will be predictable based upon their attitude towards the platform, status, gender and first language. (Rejected) H05: MSc students' knowledge of using e-learning platform will not be predictable based upon their attitude towards the platform, status, gender and first language. (Accepted)

To test hypothesis H5, standard multiple regression was used. The output is shown in Table 3.10. The model summary shows that the value of adjusted $\mathrm{R}$ square was -0.010 indicating that the model does not explain the knowledge score at all. The ANOVA Table 3.11 gives the significance level of the model as a whole as 0.46 which indicates that the contributions of the four independent variables to explaining the knowledge scores is not statistically significant.

Table 3.10

Model Summary

\begin{tabular}{|c|c|r|r|c|}
\hline Model & $\mathrm{R}$ & $\mathrm{R}$ Square & $\begin{array}{c}\text { Adjusted R } \\
\text { Square }\end{array}$ & $\begin{array}{c}\text { Std. Error of the } \\
\text { Estimate }\end{array}$ \\
\hline-1 & $.366^{\mathrm{a}}$ & .134 & $-.010-$ & 1.88256 \\
\hline
\end{tabular}

a. Predictors: (Constant), total attitude, fstlang, Gender, Status

Table 3.11 ANOVA ${ }^{b}$

\begin{tabular}{|l|r|r|r|r|r|}
\hline Model & \multicolumn{1}{|c|}{$\begin{array}{c}\text { Sum of } \\
\text { Squares }\end{array}$} & \multicolumn{1}{c|}{ Df } & \multicolumn{1}{c|}{$\begin{array}{c}\text { Sean } \\
\text { Square }\end{array}$} & \multicolumn{1}{c|}{ F } & Sig. \\
\hline 1 Regression & 13.150 & 4 & 3.288 & .928 & .46 \\
Residual & 85.057 & 24 & 3.544 & & \\
Total & 98.207 & 28 & & & \\
\hline
\end{tabular}

a. Predictors: (Constant), total attitude, fstlang, Gender, Status

b. Dependent Variable: total knowledge

Looking at the beta values in Table 3.12 shows that status is the independent variable that makes the largest contribution to explaining the dependent variable (knowledge) $($ beta $=0.46)$, though it is not statistically significant $(\mathrm{p}>0.05)$.

Table 3.12 Coefficients ${ }^{\text {a }}$

\begin{tabular}{|c|c|c|c|c|c|}
\hline \multirow[t]{2}{*}{ Model } & \multicolumn{2}{|c|}{$\begin{array}{l}\text { Unstandardized } \\
\text { Coefficients }\end{array}$} & \multirow{2}{*}{$\begin{array}{c}\text { Standardized } \\
\text { Coefficients }\end{array}$} & \multirow[b]{2}{*}{$\mathrm{t}$} & \multirow[b]{2}{*}{ Sig. } \\
\hline & $\mathrm{B}$ & Std. Error & & & \\
\hline 1 (Constant) & 2.166 & 3.139 & & .690 & .497 \\
\hline Gender & .063 & .737 & .017 & .085 & .933 \\
\hline Status & 1.829 & 1.094 & .460 & 1.671 & .108 \\
\hline fstlang & .737 & .923 & .185 & .798 & .432 \\
\hline $\begin{array}{l}\text { Total } \\
\text { attitude }\end{array}$ & $-.008-$ & .032 & $-.059-$ & $-.244-$ & .809 \\
\hline
\end{tabular}

Dependent Variable: total knowledge

The result of the multiple regression revealed that hypothesis H5 is rejected and null hypothesis H05 is accepted.

\section{Results of hypothesis H6}

H6: The students' attitude towards using e-learning platform will be predictable based upon their knowledge of using the platform, status, gender and first language.

H06: The students' attitude towards using e-learning platform will not be predictable based upon their knowledge of using the platform, status, gender and first language. 
A similar procedure was carried out to test hypothesis H6. The value of adjusted $\mathrm{R}$ square was 0.28 meaning that $28 \%$ of the variance in total attitude score was accounted for by this model (Table 3.13). The model as a whole was statistically significant at the 5\% level (Table 3.14). From the Coefficients Table 3.15 , the value of beta for status was 0.69 showing that it is status that makes the largest contribution to predicting the attitude score $(\mathrm{p}<0.05)$.

Table 3.13

Variables Entered/ Removed ${ }^{\text {b }}$

\begin{tabular}{|c|l|r|r|}
\hline Model & Variables Entered & $\begin{array}{r}\text { Variables } \\
\text { Removed }\end{array}$ & $\begin{array}{c}\text { Metho } \\
\mathrm{d}\end{array}$ \\
\hline 1 & $\begin{array}{l}\text { Total knowledge, } \\
\text { Gender, firsts } \\
\text { language, Status }\end{array}$ & & Enter \\
\hline
\end{tabular}

a. All requested variables entered.

b. Dependent Variable: total attitude

Table 3.14

Model Summary

\begin{tabular}{|c|c|r|r|c|}
\hline Model & $\mathrm{R}$ & $\begin{array}{c}\mathrm{R} \\
\text { Square }\end{array}$ & $\begin{array}{c}\text { Adjusted R } \\
\text { Square }\end{array}$ & $\begin{array}{c}\text { Std. Error of the } \\
\text { Estimate }\end{array}$ \\
\hline-1 & $.618^{\mathrm{a}}$ & .382 & .279 & 11.97281 \\
\hline
\end{tabular}

a. Predictors: (Constant), total knowledge, Gender, fstlang, Status

Table 3.15

Coefficients $^{\text {a }}$

\begin{tabular}{|l|r|r|r|r|r|}
\hline Model & \multicolumn{2}{|c|}{$\begin{array}{c}\text { Unstandardized } \\
\text { Coefficients }\end{array}$} & $\begin{array}{c}\text { Standardized } \\
\text { Coefficients }\end{array}$ & & \\
\cline { 2 - 4 } & \multicolumn{1}{|c|}{$\mathrm{B}$} & \multicolumn{1}{c|}{$\begin{array}{c}\text { Std. } \\
\text { Error }\end{array}$} & \multicolumn{1}{|c|}{ Beta } & \multicolumn{1}{c|}{$\mathrm{t}$} & \multicolumn{1}{c|}{ Sig. } \\
\hline 1 (Constant) & 47.259 & 17.704 & & 2.669 & .013 \\
Gender & $-4.474-$ & 4.596 & $-.161-$ & $-.974-$ & .340 \\
Status & 20.679 & 6.020 & .691 & 3.435 & .002 \\
fstlang & 5.568 & 5.838 & .186 & .954 & .350 \\
Total & $-.317-$ & 1.297 & $-.042-$ & $-.244-$ & .809 \\
knowledge & & & & & \\
\hline
\end{tabular}

a. Dependent Variable: total attitude

Therefore, hypothesis H6 is confirmed to the extent that status is the predictor of the attitude whereas gender, first language and knowledge do not help in the prediction.

\section{Additional statistics}

It is worth mentioning briefly that an additional statistical test has been done to clarify the influence of age on the students' knowledge of and attitude towards using e-learning platform networks among the students. The students were divided into three age groups (20-29, 30-39, 40 and over). In general, it can be argued that younger students seem to have a more positive attitude towards using e-learning platforms than their older colleagues. Regarding their knowledge of using elearning platform, it was found that students in the age group 20-29 have the highest knowledge score, while the students in the age group 30-39 have the lowest knowledge score.

\section{Discussion}

This study examined the knowledge of graduate students using the e-learning platform and their attitude towards this experience as part of a training course at a British university. The results revealed the first hypothesis that there is no statistically significant relationship between students' knowledge and their attitudes toward using the e-learning platforms. A possible explanation for this result may be a) that all students registered in the e-learning platform are required to deal across the platform and perform a variety of tasks on the network regardless. Considering their attitude towards it, even if the amount of their knowledge of the use is weak, b) the urgent necessity of using it imposed on them to deal with the community where there is no other alternative to study, c) their awareness and awareness of the importance of dealing with the platform as it is one of the tools of the era d) the training courses that It was established for them to develop the skills of using the platform's tools, and this result differs with the results of studies which indicated that the acquisition of user skills promotes the development of a positive trend towards e-learning [17]; [18]; [19]; [20].

The results of the study indicated that there is a positive trend towards using the e-learning platform among students registered through the e-learning platform more than students registered on the campus, and this may be because students registered through the e-learning platform spend significantly more time on the course materials. Compared to students on campus, where training courses through the e-learning platform create learning situations in which students are more responsible for their own learning, as it is the only way to communicate with content. Thus, online courses and the use of e-learning tools engage students in the learning process. which has gained them a positive attitude towards e-learning more than students on campus, which has many opportunities for a variety of resources, such as interactions and participation with peers and teachers and interaction from time to time with academic staff. This result is consistent with the results indicated that students registered through the e-learning platform have a sense of personal responsibility for learning [21]; [22]; [23]. The results of the present study differed from the results that revealed that there were no statistically significant differences in students' attitudes towards e-learning when comparing online courses, mixed courses, and oncampus courses [24]; [25]

The study results also indicated that there are no statistically significant differences due to the effect of gender. The researcher attributes this result to the students' awareness and desire to use the e-learning platform because they are aware of its importance and that it may help in facilitating the educational process. In fact that most students learn together at the university, and their equal involvement in the courses training and other training, in addition to the similarity of the cultural and social environment in which they work and live in general, as well as the competition that occurs between students in acquiring skills, technological experiences, 
electronic tests, the use of educational websites to communicate between the teacher and his students, the publication of online courses, and others.

Although this study shows that there is no significant difference in the attitude towards the use of the platform between male and female students, by comparing the average (male $=77.3$ and female $=73.4)$, it appears that male students are more favorable to the e-learning platform than female students, perhaps with a sample Larger, this difference may be statistically significant. The results of the present study are in agreement with the results of in their results indicated that there were no statistically significant differences between the averages of the sample estimates according to the variable of sex, [23]; [26]; [27]. and differed with the results of the study which revealed that males tend to be more positive in using technology in education than their female colleagues [28].

The study results also revealed that there is no significant difference in the trend towards using the e-learning platform among students based on their first language. However, the two subgroups' mean scores show that English speakers scored 78.1 while the other students scored 74.3. This finding could explain the idea that students whose first language is English may be more confident in writing and discussing online because they communicate in their native language, while other students may be reluctant to do so due to their language difficulties. Again, with a larger sample, this difference may be statistically significant.

Regarding the prediction of students' knowledge and attitude towards the use of the platform based on other variables (status, gender, first language). It was found that the students' condition is an indicator of the position, which may indicate further study was conducted to investigate new factors that may affect students' knowledge and attitude towards the use of the e-learning platform, for example, their knowledge and attitude towards computers and technology in general, and their specializations and satisfaction with the training course.

\section{Conclusion}

This study highlighted several interesting findings regarding the students' knowledge of and attitude towards using elearning platform. Generally, the results indicate that the students' knowledge and attitude cannot be predicted based on the other variables except their status, which is, therefore, the only predictor of their attitude towards using e-learning platform. This is related to the finding that distance learning students have a more positive attitude towards using the platform than their on-campus colleagues, whose attitude tends to be negative. Additionally, there is no significant correlation between the students' knowledge and attitude, which could be explained, as previously mentioned, by the fact that all students attended a training session about how to use elearning platform regardless of their attitude towards it and their background. In short, this issue needs to be investigated with a larger sample considering the sub-groups and other factors that could impact the students' knowledge and attitude, as mentioned in the discussion. It could also be useful if other students, tutors, and researchers who use e-learning platform were included in further studies.

\section{Suggestion for Further Study}

It is suggested to provide a more comprehensive and richer study, another area of future research, which is implementing the test before and after the student's participation in a course with e-learning tools to measure the differential gains of students' perception of e-learning tools. A final suggestion for future research is to investigate the effectiveness of combined courses to determine the best combination of campus-based versus deep learning interactions.

Developing students' capabilities and enhancing them through training programs to familiarize themselves with modern technology in dealing with e-learning programs.

Research on student learning is supported. What must remain central to our pursuit of knowledge regarding e-learning tools is our students and how these tools' learning environments improve student performance..

\section{References}

[1] Eynon, R. (2005). The use of the internet in higher education: academics' experiences of using ICTs for teaching and learning. Aslib Proceedings: New Information perspectives, 57:168-180.

[2] Macharia, PhD, Jimmy \& Pelser, Theuns. (2012). Key factors that influence the diffusion and infusion of information and communication technologies in Kenyan higher education. Studies in Higher Education. 39. 695709. 10.1080/03075079.2012.729033.

[3] Mishra, P., \& Koehler, M. J. (2007). Technological pedagogical content knowledge (TPCK): Confronting the wicked problems of teaching with technology. Technology and Teacher Education Annual, 18(4), 2214.

[4] Cappel, J. J.; Hayen, R. L. (2004). Evaluating e-learning: A case study. // Journal of Computer Information Systems, 44, 4, 49-56.

[5] Douglas, D. E.;Van DerVyver,G. (2004). Effectiveness of e-learning course materials for learning database management systems: An experimental investigation. // Journal of Computer Information Systems, 44, 4, 41-48.

[6] Millson, M. R.;Wilemon, D. (2008). Educational Quality Correlates of Online Graduate Management education. // Journal of Distance Education, 22, 3, 1-18.

[7] Allen, I. E., \& Seaman, J. (2011). Going the distance: Online education in the United States 2011. Babson Survey Research Group, Babson College. Retrieved from http://www.babson.edu/Academics/centers/blankcenter/gl obalresearch/Documents/going-the-distance.pdf

[8] Williams, Jeremy \& Jacobs, Joanne. (2004). Exploring the Use of Blogs as Learning Spaces in the Higher Education Sector. Australasian Journal of Educational Technology. 20. 10.14742/ajet.1361.

[9] Armstrong, D. A. (2011). Students' perceptions of online learning and instructional tools: A qualitative study of 
undergraduate students use of online tools. The Turkish Online Journal of Educational Technology, 10, 222-226

[10] Holmes, C. M., \& Kozlowski, K. A. (2014). "Tech support": Implementing professional development to assist higher education faculty to teach with technology. Journal of Continuing Education and Professional Development, 2(1), 9-20. doi:10.7726/jcepd.2015.1002

[11] Sime, D. and Priestley, M. (2005). Student teachers' first reflections on information and communication technology and classroom learning: implications for initial teacher education. Journal of computer assisted learning, 21:130142

[12] Postholm, May. (2007). The advantages and disadvantages of using ICT as a mediating artefact in classrooms compared to alternative tools. Teachers and Teaching: theory and practice. 13. 587-599. 10.1080/13540600701683531.

[13] Kalogiannakis, Michail. (2010). Training with ICT for ICT from the trainee's perspective. A local ICT teacher training experience. Education and Information Technologies. 15. 3-17. 10.1007/s10639-008-9079-3.

[14] Creswell, John. (2009). Research Design: Qualitative, Quantitative, and Mixed-Method Approaches.

[15] Pallant, J. (2010). SPSS Survival manual: A step by step guide to data analysis using SPSS for windows. Australia: Open University Press/ McGraw Hill Education.

[16] Oppenheim, A. N. (1992) Questionnaire Design, Interviewing and Attitude Measurement, New York: Wellington House.

[17] Al-Bahnasawi, Abeer Abdel Halim, Salem, and Reham Al-Sayed (2020). The use of participatory learning based on the tools of the second generation web.0.2 in developing the skills of designing electronic teaching and the trend towards Internet-based learning among students, biological sciences teachers, Journal of the College of Education, 31 (121), pp. 188-246.

[18] Al-Baz / Marwa Muhammad Al-Baz (2013). The effectiveness of a training program based on e-learning in developing the skills of e-teaching and the trend towards it among science teachers during service, Journal of Practical Education, Egyptian Society for Practical Education, 16 (2).

[19]Ben Sharif, Lakjal (2013). Student attitudes towards digital technology in higher education (field study at Saida University), Master Thesis, Faculty of Letters, Languages, Social Sciences and Humanities, Saida University, Algeria.

[20] Al-Jabri, Nahel (2011). Attitudes of university students and professors towards e-learning, Alexandria University, $3(6)$.

[21] Holzweiss, Peggy \& Joyner, Sheila \& Fuller, Matthew \& Henderson, Susan \& Young, Robert. (2014). Online graduate students' perceptions of best learning experiences. Distance $\quad 35$. 10.1080/01587919.2015.955262.

[22] Idlbi, Ziad. (2020). Factors affecting the intention and use of e-learning, a field study in the companies of the industrial sector in Syrian. 10.13140 / RG.2.2.27394.43202.

[23] Saadat, Khalil Ibrahim (2011). The possibility of using distance education in the programs of the College of Applied Studies and Community Service at King Faisal University in Al-Ahsa - An exploratory study, Damascus University Journal, 12 (1).

[24] Attia, Jibreen, and Al-Matari Muhammad, Reem Omar (2010) Analysis of the attitudes of graduate students at the Hashemite University towards e-learning applications, Education in a Changing World Conference, Zarqa Jordan April 7-8, 2010

[25] Al-Juhani, Saeed Lily (2016). Investigating the Behavioral Intentions of graduate female students to Use Edmodo Instructional Platform in the Future by Using the Technology Acceptance Model (TAM), Journal of the College of Basic Education for Educational and Human Sciences, University of Babylon, Issue 28.

[26] Rakha, Muhammad Hassan (2020). Implementing the Classroom Google e-learning management system at the College of Physical Education in Port Said during the Corona pandemic: An Analytical Study, The Scientific Journal of Research and Studies in Physical Education, Port Said University, P (40).

[27] Yousef, Othman Al-Youssef (2020). Student attitudes towards e-learning in light of the Corona pandemic, AlHikma Journal for Media and Communication Studies, 8 (3), 12-47.

[28] Al-Sharif, Basem Bin Nayef (2019). The reality of university students 'trends towards cleaning up digital platforms in university education in the Kingdom of Saudi Arabia (Taibah University as a model), Taibah University Journal of Arts and Humanities 7 (22).

\section{Creative Commons Attribution License 4.0 (Attribution 4.0 International, CC BY 4.0)}

This article is published under the terms of the Creative Commons Attribution License 4.0

https://creativecommons.org/licenses/by/4.0/deed.en_US 